Eurasian Journal of Educational Research
www.ejer.com.tr

\title{
Views of Teachers Regarding the Life Skills Provided in Science Curriculum*
}

Dilek ERDURAN $\mathrm{AVCI}^{1}$, Damla KAMER ${ }^{2}$

\begin{tabular}{|c|c|}
\hline ARTICLE INFO & A B STRACT \\
\hline $\begin{array}{l}\text { Article History: } \\
\text { Received: } 18 \text { Dec. } 2017 \\
\text { Received in revised form: } 26 \text { Jul. } 2018 \\
\text { Accepted: } 05 \text { Sept. } 2018 \\
\text { DOI: } 10.14689 / \text { ejer.2018.77.1 } \\
\text { Keywords } \\
\text { 4-H life skills, science literacy, } \\
\text { teachers' perceptions, science course }\end{array}$ & $\begin{array}{l}\text { Purpose: Teachers have an important role to help } \\
\text { their students acquire and improve their life skills. } \\
\text { Therefore, it is essential to ask what science teachers } \\
\text { think about the concept of life skills and how they } \\
\text { perceive this concept. The aim of this study was to } \\
\text { examine how science teachers perceive life skills and } \\
\text { what they think about life skills as part of the learning } \\
\text { process in Turkish Science Course Curriculum. } \\
\text { Research Methods: This research was conducted as a } \\
\text { case-study. } 26 \text { science teachers, who worked in the } \\
\text { centre of Burdur province, participated in the study. } \\
\text { Data were collected with semi-structured interviews. } \\
\text { Findings: This study revealed that science teachers } \\
\text { believed that life skills are necessary for every } \\
\text { individual but when it was assessed according to } \\
\text { Turkish Science Course Curriculum, awareness of } \\
\text { relating life skills to daily life was significantly low. }\end{array}$ \\
\hline \multicolumn{2}{|c|}{$\begin{array}{l}\text { Most teachers perceived life skills limited only to their own branch of education (e.g., science). } \\
\text { Implications for Research and Practice: It was essential for us to increase the level of teacher } \\
\text { awareness about life skills, which are integrated to the curriculum, in order to make the } \\
\text { students gain and/or improve the life skills required in the } 21 \text { st century. We propose that new } \\
\text { policies, which focus on pre-service and in-service educational activities that help teachers to } \\
\text { improve their vocational qualifications to integrate their own life skills with the courses, should } \\
\text { be developed. }\end{array}$} \\
\hline
\end{tabular}

(C) 2018 Ani Publishing Ltd. All rights reserved

\footnotetext{
* This study was presented at the International Congress of Eurasian Educational Researches held in Mugla on May 31-3 June, 2016.

1 Mehmet Akif Ersoy University, TURKEY, e-mail: derduran@mehmetakif.edu.tr, ORCID https://orcid.org/0000-0001-6695- 7348

2 Private Palmiye Middle School, TURKEY, e-mail: damlaozdemirsun@gmail.com, ORCID: https:/ / orcid.org/0000-0002-0376- 6736
} 


\section{Introduction}

As our world moves from the industrial age of 20th century to the information age of 21st century, we become more and more aware of the fact that the skills which lead to success in the 20th century do not guarantee success in the 21st century (Kivunja, 2015). This awareness reveals the skill demand and supply gap for the business world (OECD, 2016, p.3). Recent studies indicated an increase in difficulties that employers have been encountering in filling vacant positions (Cedefop, 2018). This problem is also known as the "21st-century skills gap" (Trilling \& Fadel, 2009, p.7) or "skill mismatch" (Cedefop, 2018) in the business world. The competitive capacity and wealth of a country depends on having a qualified and well-educated workforce (Trilling \& Fadel, 2009, p.7). This dependency makes the information-era world face the demand for growing individuals who have a new series of skills.

Life skills are the ones that are among the 21st-century skills (Partnership for 21st Century Skills [P21], 2015) and help us cope with daily life problems effectively (World Health Organization [WHO], 1997). Many worldwide organizations conduct educational activities which develop life skills for individuals (UNESCO, 2004; United Nations, 2003; WHO, 1997). All of these organizations consider life skills as necessary skills that help individuals to effectively manage the problems they encounter and believe it important to adopt into their life. Furthermore, these organizations emphasize the need to develop such skills to insure individuals align themselves with the demands of the information age.

Thus, some questions arise, first, "What are the necessary life skills in the 21st century?" There are many studies in the literature that classify life skills in various forms (Fox, Schroeder \& Lodl, 2003; Hanbury, 2008, p.10; Hendricks, 1998; P21, 2015; United Nations, 2003). One of the most comprehensive classifications belongs to Hendricks (1998), who organized a model called 4-H life skills. These skills are divided into four main categories; Head (managing and thinking), Heart (relating and caring), Hand (giving and working), and Health (being and living). Life and career skills are grouped as flexibility \& adaptability, initiative \& self-direction, social \& cross-cultural skills, productivity \& accountability, leadership \& responsibility in the P21 project (P21, 2015). Fox, Schroeder, and Lodl (2003) classified a total of 32 life skills under four themes (e.g., technical, communication, personal/social and leadership skills). WHO (1997) emphasizes that the nature of these skills may differ depending on the cultures and defines the main skill set for the life skills as decision making, problem-solving, creative thinking, critical thinking, effective communication, interpersonal skills, self-awareness, empathy, managing emotions, and stress. The skills that WHO has pointed out, are also common skills found in many of the classifications within the research literature.

The second question; "What are the level definitions for the skills that are essential in the 21st century and how can they be adopted in the curricula?" An important step for this question was the official approval of "The European Qualifications Framework for life-long learning" (EQF) in April 2008 by the European Parliament and European Council (European Communities, 2008). The 
foundation of EQF is formed by eight levels which define minimum common qualifications and these levels are defined as "level indicators" that are formed by learning acquisitions including information, skills, and competence. In the last decade, many countries, most of which are European countries (e.g., Czech Republic, Spain, Italy, Lithuania), have accomplished national reforms in their national curricula aligned with the key competencies defined in the EQF (European Commission/EACEA/Eurydice, 2012). One of the purposes of these reforms was to develop the life skills of students in order to prepare them for life.

Turkey also tool steps in this direction by forming the national competency framework in 2015 according to the EQF (Turkish Qualification Framework [TQF], 2015), and completed the reforms, during which the competencies and the skills emphasized in the framework were inserted in the national curricula (The Turkish Ministry of National Education [TMNE], 2018). The life skills topic was included in Turkish Science Course Curriculum (TSCC) for the first time before this reform (The Turkish Ministry of National Education [TMNE], 2013). The purpose was to instruct and develop the life skills like analytical thinking, decision making, creative thinking, entrepreneurship, communication, and team-work together with the basic information. All of these life skills were included in TSCC as sub-learning domains. Among the primary objectives of the TSCC, the one regarding life skills was expressed as (TMNE, 2013); “To make every individual take responsibility of daily life problems and to make them make use of information gained from science courses, scientific process skills, and other life skills" (p. II).

The findings of "21st Century Skills and Competences for New Millennium Learners in OECD Countries" (2009) indicated that the introduction of 21st-century skills has been conducted via reforms in compulsory education curricula in many countries, including Turkey. On the other hand, there are no national or regional policies to shape or summarize these skills. Similarly, there are only a limited number of teacher education policies that target instruction and development of the stated skills. The report emphasized the absence of policies for teachers to instruct and assess these skills (Ananiadou \& Claro, 2009). Although Turkey's attempt to conduct curricula reforms in the same period with many other countries was considered as a positive development, a research study (Turkish Education Association [TEA], 2009) indicated that the teachers could not follow the changes in the curricula.

The third question; "What do we need to support the education and the instruction process for the skills required in the 21st century?" Our age demands individuals who have a new skill set (Kaufman, 2013; Trilling \& Fadel, 2009, p.8). Kivunja (2014) claimed that this demand can be satisfied with a new learning paradigm; for example, "Teaching our students so that they become well-equipped with the 21st-century skills is the new learning paradigm" (p. 85). According to Kivunja, this paradigm shift process can only be sustained by providing students with the required education to master the skills that are essential in the 21st century. At this point, the studies which support the understanding and applying of life skills, essential in the 21st century, are quite limited for both the students (Ansari, Khorram, 
Soleimaninejad \&Ansari-Moghaddam, 2016; Erawan, 2010; Kennedy, Pearson, BrettTaylor \& Talreja, 2014; Saavedra \& Opfer, 2012; Svanemyr, Baig \& Chandra-Mouli, 2015; Trilling \& Fadel, 2009, p.125; Wallace \& Priestley, 2011) and the teachers, teacher candidates, and/or teacher educators (Avsar, 2007; Bacanak, 2013; Raja, Mullaikodi \& Asaph, 2015; Suminar, Prihatin \& Syarif, 2016).

Suminar, Prihatin, and Syarif (2016) stated that the professional skills of instructors are limited when it comes to understanding the scope and objective of life skills instruction, which leads to ineffective planning and realization of the learning process. Ansari et al., (2016) pointed out that medical students are often not aware of the importance of life skills and the authorities do not implement programs in this field. Gunes and Uygun (2016) indicated that they found a gap between the required teacher information \& skill set and the information \& skill set put into practice by the teachers. Then, they emphasized that this gap negatively affected the skill mismatch problem. Here, we can name the "good teachers" as the answer to our third question (Darling-Hammond, 2006; Kaufman, 2013; Saavedra \& Opfer, 2012; Trilling \& Fadel, 2009). Trilling and Fadel (2009) emphasized that teachers should be effective in the following process; "They will need to be well coordinated with ongoing changes in curriculum, assessment, standards, and the overall learning environment" (p.139). Ananiadou and Claro (2009) claimed that the attempts related to the aforementioned skills can only be realized if both teachers and students consider them worthy and useful for their teaching and learning experiences.

In Turkey, the Ministry of Education has been trying to realize the attempts to support life skills instruction with curricula reforms that cover compulsory education for a term of five years (TMNE, 2013, 2018). Science teachers are undoubtedly the pioneer practitioners who are supposed to integrate the life skills which were included in TSCC in 2013 for the first time into the classrooms. Therefore, we think that finding out the views of the science teachers about these skills included in the TSCC has a great importance in developing teacher education policies which will help us overcome the skill mismatch problem and to grow individuals who possess the required life skills. This study aimed to find out how Turkish science teachers perceived life skills, and what their opinions about the inclusion of life skills into the TSCC. The following research questions were asked:

1. How do Turkish science teachers perceive life skills?

2. What do Turkish science teachers think about the inclusion of life skills in the TSCC?

\section{Method}

\section{Research Design}

This research was designed as a case study, which is a qualitative research method. The case study approach is an empirical research method which studies a phenomenon within its real-life framework, in which boundaries between the fact 
and the content are not clear, and which is used when more than one form of evidence or source of data is available (Yildirim \& Simsek, 2011, p.277). In this study, the case study design was chosen to find out the views of science teachers about life skills in the TSCC.

\section{Research Sample}

In this study, purposeful sampling method was used because it allowed an indepth study of the case (Yildirim \& Simsek, 2011, p.107). In this context, we asked all of the science teachers employed in the secondary schools in Burdur province to participate in this research, and we received positive replies from 26 of the contacted teachers. 13 of the participants were male and the remaining 13 were female. They were employed in 13 different secondary schools. The teachers' ages ranged from 28 to 56 , and the teachers had 6 to 35 years of working experience. 24 of the participants had a bachelor's degree. One participant was studying for a master's degree in science education and the other had completed a master's degree in physics. 20 of the teachers were graduates from the education faculty, 4 of them were graduates from science and literature faculties, and 2 of them were graduates from an education institute (e.g., a previously established 3-year duration teacher training institution).

\section{Research Instruments and Procedures}

An interview form was used as the research instrument. The interview form included questions about the demographic characteristics of teachers, what life skills mean for them, what they think about life skills being included in the TSCC, how they assess the acquisition of life skills (e.g., analytical thinking, decision making, creative thinking, entrepreneurship, communication, and teamwork) in science classes, the effectiveness of their own lessons to acquire these skills, how they practice the acquisition of these skills, what limitations and restrictions are there to acquiring these skills, and so forth. The researchers received expert support to compose the content of the form and to validate it linguistically. In the pilot study, 5 science teachers were interviewed in order to determine the question order and to find out the alternative questions, in case they were required. After the pilot study, the researchers presented the form to an expert and asked for feedback. Then the interview form including 13 questions, supported by the common view of experts and researchers, was finalized.

The researcher introduced herself to the participants and defined the aim of the study in their preliminary interview. At that time, the date and time were set for the participants' main interviews. The researcher met the teachers on their scheduled appointment dates in appropriate offices at the schools in which they worked. The interviews were semi-structured and recorded with a voice recorder.

\section{Validity and Reliability}

109 codes were generated during the data analyses of teachers' perceptions of life skills. Two experts collaborated in the code generation process. These codes were organized under themes according to their similarities. Two other experts 
commented on the codes and the inter-rater reliability value was calculated at 93.57. A framework for data analysis was established using six life skills in the TSCC and this framework was employed in the descriptive analysis of the views about life skills in the TSCC.

\section{Data Analyses}

Content analyses and descriptive analyses were used in the data analyses process. The collected data were transcribed and then divided into two meaningful sections; "Teachers' Perceptions of Life Skills" and "Views about the Inclusion of Life Skills in the TSCC". Content analysis was applied to the first section and descriptive analysis was applied to the second section. In content analyses, similar data were gathered together within certain concepts and themes and interpreted in a meaningful way, whereas in the descriptive analyses, data were summarized according to previously determined themes (Yildirim \& Simsek, 2011, p.224-227).

\section{Results}

\section{Teachers' Perceptions of Life Skills}

Teachers' perceptions of life skills as themes and sub-themes are presented in Table 1. According to Table 1, ten of the teachers related life skills to science literacy, three of them related life skills to the 4-H life skills model, and 13 of them related life skills to both science literacy and 4-H life skills.

\section{Table 1}

The Themes of Teachers' Perceptions of Life Skills and Their Distribution

\begin{tabular}{llll}
\hline Themes & Sub-themes & $\mathbf{f}$ & $\mathbf{N}$ \\
\hline \multirow{3}{*}{ Science literacy } & Key science conceptions & 16 & \\
& SPS & 5 & 23 \\
& STSE & 45 & \\
& Scientific and technical psychomotor & 9 & \\
& skills & & \\
& Thinking & 11 \\
4-H Life Skills & Managing & 11 & 16 \\
& Relating & 6 & \\
& Caring & 2 & 1 \\
\hline
\end{tabular}

(SPS: Science Process Skills, STSE: Science-Technology-Society-Environment, f: frequency, N: number of teachers)

\section{Science Literacy}

It was observed that 23 teachers' perceptions of life skills included the theme of science literacy. These teachers perceived life skills as applying scientific knowledge in everyday life, measuring, making observations, having knowledge about scientific 
concepts and understanding these concepts. According to these teachers, learners who possess life skills use scientific knowledge outside of school and remember scientific explanations of events they observe in their environment. These teachers related the concept of life skills to their particular academic background and thought that a student, who used the knowledge that an acid and base react when they are mixed, demonstrated a life skill. According to them, a student having life skills should know the scientific reasons underlying a solar or lunar eclipse or tidal events, should have the knowledge of the human body, should remember about health, and should make use of the scientific knowledge. As shown in Table 1, teachers' examples were related to science literacy's sub-themes which are; "Key Science Conceptions", "Science Process Skills" (SPS), "Science-Technology-SocietyEnvironment" (STSE) and "Scientific and Technical Psychomotor Skills". Four examples of teachers' quotes related to these sub-themes are presented below:

“... Children should apply scientific knowledge in daily life. We teach acids and bases. If a child goes home and remembers not to mix them or I mean, when he looks at a substance then he knows it is made of molecules ... I've recently bought a kidney from the butcher. My daughter asked me 'We will wash it before we eat it, won't we?' then I asked: 'Why?' She answered 'Its job is to filter urine, isn't it? So it is dirty'. Isn't this a life skill?" (Erdinc) (Key science conceptions)

“... I want to teach how to observe something. I tell students 'Observe very carefully, look very carefully'. Everything in life is related to science." (Perihan) (SPS)

"... We can teach them how long a plastic bag can dissolve in nature, but we cannot show that a child should throw it in the recycling box." (Salih) (STSE)

“... Many things might be a skill. But you see that children are not even able to do simple things ... They cannot draw anything, they cannot even write or cut something ..." (Keriman) (Scientific and Technical Psychomotor Skills)

\section{4-H Life Skills}

Some examples cited by 16 teachers were related to certain skills from the $4-\mathrm{H}$ life skills model. The examples under this theme define life skills as dealing with problems faced in individual or social life. The skills, such as being responsible, being able to see the future, adapting to life, honesty, self-confidence, time management, achieving success, and communication were considered in this theme. Teachers' examples were related to six of eight life skills in the 4-H model. These six skills presented in Table 1 are thinking, managing, relating, caring, living and being. An interesting finding here is that; there were no examples of life skills that belong to the working and caring categories of the 4- $\mathrm{H}$ model, namely self-motivation, teamwork, empathy, sharing, and caring for others, among the examples given by the teachers.

Ahmet's examples were entrepreneurship, self-expression, choosing a suitable occupation, and critical interpretation. According to him, it was necessary to have life 
skills in order to have a professional career. Latif said that all the skills that enabled students to grow up to good citizens and enabled them to survive in the future were life skills. Latif stated; "For example, decision-making might be a life skill ... taking responsibility, communication, self-expression, self-confidence, creative thinking might be life skills also." Gamze defined life skills as, "solving problems within the family, friendships and social interaction in everyday life".

\section{Views about the Inclusion of Life Skills in the TSCC}

15 teachers stated that they had closely examined the TSCC, 5 teachers said that they just quickly reviewed it, and 6 teachers said that they did not examine the TSCC at all. Also, all of the teachers stated that they did not have any in-service training related to TSCC. Only one teacher said that he/she had noticed there was a learning area in the TSCC named life skills. After learning about it, 19 teachers had a positive opinion about the inclusion of the life skills in the TSCC, while 6 teachers said that the inclusion of the life skills in the TSCC was not beneficial because of the inability to perform the relevant activities. One teacher did not want to comment. Ahmet, who had a positive opinion, stated, "It is good for future generations. I think life skills are necessary for anyone to survive. It is beneficial for both the society and the individual." Erdinc, who thought the inclusion of the life skills in the TSCC brought no benefit at all, stated,

"Unless the course duration is changed, the weight of the topics is reduced, we have any extra time for experiments, and the central examination system is cancelled, inclusion of the life skills in the curriculum has no meaning... According to the curriculum, we must apply this. So, we're going to do it just because it says so? Has the curriculum been relaxed accordingly? Is the infrastructure prepared?"

Views about Six Life Skills in the TSCC

Analytical thinking. Among the teachers, 20 of them said that science was an appropriate subject for the acquisition of analytical thinking skills; however, they also thought that each unit was not equally suited to acquire the corresponding skill. They thought that research homework, concept maps, a puzzle method, student clubs, the 5E method, and project competitions were all relevant in developing analytical thinking skills. For example, Ahmet said, "Concept maps already go to the whole from parts... Students already apply analytical thinking to reach the whole." Fahri stated that he enabled students to acquire analytical thinking skills through the method he called "puzzle method". Another three teachers thought that mathematics, Turkish, or social studies were more appropriate subjects for achieving this skill and they argued that the science course was not suitable for achieving this skill. One of the teachers said that due to their age, analytical thinking skills might be possessed by students at the high school or university level.

Decision making. 19 teachers thought that the skill of decision-making was an appropriate skill to acquire in science class. They stated that experiments, teamwork, brainstorming, trips out of school, and other similar activities helped in the acquisition of the decision-making skill. Of these activities, making experiments was 
the most dominant one, which was emphasized by 13 teachers, while seven of the teachers did not agree. These seven teachers instead thought that acquiring this skill depended on reading books, being confident, the socio-economic status of the family, attitudes between parents and the children, and similar variables.

Creative thinking. 24 teachers believed that creative thinking was an appropriate skill to acquire in science class. One of the other teachers believed that the creative thinking skill was a genetic property, and another one believed that this skill could be acquired by reading books. Some of the teachers explained that they could unfortunately not do activities to develop creative thinking skills because of the number of learning objectives in TSCC, the necessity of preparing the students for the central examinations, economic inadequacies, and the lack of materials. Other teachers stated that they tried to do activities to support the skill of creative thinking such as project work, open-ended questions, and event completion. The activity most frequently emphasized was project work.

Entrepreneurship. 23 teachers had positive opinions regarding this skill. They highlighted that project work, experiments, giving responsibility to students and encouraging them to be self-confident had a very positive effect on entrepreneurship. The teachers who did not have positive opinion regarding entrepreneurship thought that this skill depended on people's genetic character. They did believe though that if students had education relevant to their interests or if their class teacher helped them develop this skill at an early stage in their primary school education, they potentially could develop this skill.

Communication. All the teachers thought that science courses contributed positively to the acquisition or improvement of communication skills. Teachers believed that activities and practices such as teamwork, experiments, and presentations improved communication skills. Among them, the most emphasized activity was teamwork.

Teamwork. 16 of the teachers said that they provided opportunities for teamwork, but nine teachers preferred not to use teamwork, and only one teacher preferred it only for students in the 7th and 8th grades. Teachers stated that they performed project work, experiments, and homework presentations in the form of teamwork. According to them, students improved their sense of responsibility and communication skills through teamwork. In addition, they thought that teamwork helped students, who were passive in the classroom, to join activities in class as well as to become more active and confident. Teachers who did not provide opportunities for teamwork in their classes had the following reasons for not doing so; the central examination system, curriculum anxiety, crowded classes and ineffective use of time by students, lack of responsibility by students and communication problems. 


\section{Discussion, Conclusion and Recommendations}

In this study, two aspects of science teachers' views were examined. These views reflected their perceptions of life skills and the inclusion of life skills in the TSCC. The results of this study regarding the two aspects of the teachers are discussed in the following section.

First, the science teachers' life skills perception was examined. We found that they had two different perspectives. Most of the teachers perceived life skills as science literacy; some of them related life skills to skills found in the 4-H life skills model. Furthermore, some of the teachers considered life skills as both themes of science literacy and 4-H life skills. In fact, there is no consensus in the literature as to what life skills are and what life skills are not. The reasons why most teachers, who participated in this research, perceived life skills as science literacy could be related to the vision of the TSCC. The vision of TSCC that has been applied for more than 10 years in Turkey was to make students develop science literacy (TMNE, 2005, 2013). Teachers have internalized this vision and may have directed their students to acquire this skill in this area. Thus, the concept of life skills may have led to the teachers' examples being directly related to their own subjects. A similar result was observed in Hanbury's (2008) research about street children educators, who were asked; "What are life skills?" and the examples they provided were; "giving oral rehydration", "resisting peer pressure" and "learning from each other" which were all related to their own role. At the same time, these educators gave examples similar to science teachers' such as time management, problem-solving, decision making, creative thinking, getting a job, brushing teeth, cooking, and self-confidence.

Most of the participant science teachers related life skills to science literacy and some of them considered these skills as ones that would help a person to overcome life problems as well as to succeed in personal and social life. The example skills provided by the teachers' overlapped with six of eight skill categories (e.g., thinking, managing, relating, caring, living, and being) from the 4- $\mathrm{H}$ life skills model (Hendricks, 1998). Skills from the "being" category, such as self-respect, selfresponsibility, and feeling management, were the most emphasized ones. It was interesting that the provided life skills examples did not contain any examples related to "working" and "sharing" categories of the 4-H model such as teamwork, empathy, sharing, and caring for others. Lane, Pierson, and Givner (2004) stated in their study with a group of secondary and high school teachers, that cooperation and self-skills were among the social skills which were expected from the students. Ozturk and Bektas (2018) emphasized that pre-school teachers and first grade teachers shared a common thought about their students and they stated that their students had creative thinking and entrepreneurship as life skills.

Although a great majority of the science teachers brought examples about life skills which are related to their own branch of education (e.g., science) in our study, half of them perceived these skills as skills that existed both in science literacy and in the 4-H model. This was also emphasized in the report on life skills by UNESCO (2004); “The importance is also not to see 'life skills' in isolation, but to view a life 
skills approach as a culmination of the combination of manual skills and psychosocial abilities" (p. 5).

Secondly, the teachers' perceptions about the six life skills (e.g., analytical thinking, decision making, creative thinking, entrepreneurship, communication, and teamwork) from the TSCC (TMNE, 2018) were examined in this study. Almost all of the teachers were unaware of the fact that the life skills were included in the TSCC, and from the interviews with the teachers, we thought that the reason behind this was that the TSCC has been in practice for only one year and that the teachers had not yet received any in-service training. Nevertheless, they considered these skills to be appropriate to include in science classes. Although many did not know that these skills were included as a sub-learning area, they included these skills in their lessons. They thought that these skills could be acquired mainly through project work and experiments. Some of the teachers' approach was critical to this situation. They said that they experienced difficulties in conducting lessons to make students gain life skills according to the curriculum. According to them, students needed to participate actively in the class to acquire these skills. However, they pointed out that it was very difficult to provide education to students which included life skills due to the education system, which was based on central examinations, and had crowded classes, which make it difficult for all students to participate in these activities. Similar problems were stated by Kurtdede-Fidan and Aydogdu (2018).

Balbag, Leblebicier, Karaer, Sarikahya and Erkan (2016) argued that the reforms made in the TSCC, which aimed to enhance the effectivity of the science education process, were not enough to prevent the problems which were encountered during the education process. This study emphasized that the problems encountered in science education process between 2010 and 2015 stemmed from the teachers, physical and environmental conditions, students, and the curriculum. We think that the relation between the teacher and the curriculum may be important. In some studies, we see that some teachers were found to not be following the curriculum changes and/or reforms or they were found to not be inspecting the content of their branch curricula (Erduran-Avci, Unal \& Usak, 2014; Koyuncu \& Kavcar, 2016; TEA, 2009). This fact makes it more difficult to understand and perceive the education program as a whole (TEA, 2009). Ayvaci, Bakirci and Yildiz (2014) made it clear that most of the science teachers thought periodic in-service training activities should be conducted. Other studies with teachers from other branches of education also had similar results and the same needs (Gultekin, Cubukcu \& Dal, 2010; Ucar \& Ipek, 2006).

It is obvious that we have to update our curricula and conduct educational reforms in order for our students to gain the required information, skills and competencies (Saavedra \& Opfer, 2012). Ultimately, the teachers are the key actors in realizing the curriculum content within the classroom (Ayra \& Kosterelioglu, 2015). That is why they are expected to integrate real-life related learning opportunities regarding skills that are vital in satisfying the needs of the 21st century (Basturk, 2012; Larson \& Miller, 2011; Trilling \& Fadel, 2009). Due to the fact that contemporary teachers have a higher tendency for life-long learning (Ayra \& 
Kosterelioglu, 2015), their awareness about life skills, together with their belief in that these skills will be used by students, plays a key role in satisfying this expectation (Saavedra \& Opfer, 2012). This justifies the need for developing policies that empower the teaching profession, supports teachers, and provides them with coaching in order to solve the problem of the "21st-century skills gap" (OECD, 2013). Among these policies, it is important to combine the topics of "creating high-quality teacher education programs" (Ananiadou \& Claro, 2009; Trilling \& Fadel, 2009) and "providing effective in-service professional development for updating skills and information" (OECD, 2013) together. In this context, we think that future studies, which focus on (i) the competencies of teachers to help students gain the life skills required in the 21st century or improve their existing skills through in-class or outof-class activities, (ii) the needs of the teachers, and (iii) encouraging or discouraging/limiting factors for the teachers, might contribute to the development of aforementioned policies.

\section{References}

Ananiadou, K., \& M. Claro (2009). 21st century skills and competences for new millennium learners in OECD countries (Report No. 41). OECD Education Working Papers, OECD Publishing.

Ansari, H., Khorram, M., Soleimaninejad, A., \& Ansari-Moghaddam, A. (2016). Predictors of life skills level of students in Zahedan University of Medical Sciences in Southeast of Iran. International Journal of Epidemiologic Research, 3(1), 33-41.

Avsar, M. (2007). Yuksek ogretimde ogrencilerin girisimcilik egilimlerinin arastirilmasi, Cukurova Universitesinde bir uygulama [To determine entrepreneurship intentions of university students, study on Cukurova University students] (Unpublished Master's thesis). Cukurova Universitesi, Sosyal Bilimler Enstitusu, Adana.

Ayra, M., \& Kosterelioglu, I. (2015). Ogretmenlerin yasam boyu ogrenme egilimlerinin mesleki oz yeterlik algilari ile iliskisi [The relationship between teachers' lifelong learning tendencies and their perceptions of professional self-efficacy]. NWSA-Education Sciences, 10(1), 17-28.

Ayvaci, H.S., Bakirci, H., \& Yildiz, M. (2014). Fen bilimleri ogretmenlerinin hizmet ici egitim uygulamalarına iliskin gorusleri ve beklentileri [Science and technology teachers' views and expectations about in-service training practices]. Amasya Universitesi Egitim Fakultesi Dergisi, 3(2), 357-383.

Bacanak, A. (2013). Teachers' views about science and technology lesson effects on the development of students' entrepreneurship skills. Educational Sciences: Theory \& Practice, 13(1), 622-629. 
Balbag, Z., Leblebicier, K., Karaer, G., Sarikahya, E., \& Erkan, O. (2016). Turkiye'de fen egitimi ve ogretimi sorunlari [Science education and teaching problems in Turkey]. Egitim ve Ogretim Arastirmalari Dergisi, 5(3), 12-23.

Basturk, R. (2012). Ilkogretim ogretmenlerinin hizmet ici egitime yonelik algi ve beklentilerinin incelenmesi [Investigation of elementary school teachers' perception and expectation about in-service education]. Hacettepe Universitesi Egitim Fakultesi Dergisi, 42(2012), 96-107.

Cedefop (2018). Insights into skill shortages and skill mismatch: Learning from Cedefop's European skills and jobs survey (Cedefop reference series; No 106). Luxembourg: Publications Office.

Danish, S., Forneris, T., Hodge, K., \& Heke, I. (2004). Enhancing youth development through sport. World Leisure Journal, 46(3), 38-49. doi:10.1080/04419057.2004.9674365

Darling-Hammond, L. (2006). Constructing 21st-century teacher education. Journal of Teacher Education, 57(3), 300-314.

Erawan, P. (2010). Developing life skills scale for high school students through mixed methods research. European Journal of Scientific Research, 47(2), 169-186.

Erduran-Avci, D., Onal, N.S., \& Usak, M. (2014). Turkish teachers' opinions about science-technology-society-environment acquisitions in science and technology course curriculum. Journal of Baltic Science Education, 13(2), 216230.

European Communities (2008). The European qualifications framework for lifelong learning. Luxembourg: Office for Official Publications of the European Communities. doi: 10.2766/14352

European Commission/EACEA/Eurydice (2012). Developing key competences at school in Europe: Challenges and opportunities for policy. Eurydice report. Luxembourg: Publications Office of the European Union.

Fox, J., Schroeder, D., \& Lodl, K. (2003). Life skill development through 4-H clubs: The perspective of 4-H alumni. Journal of Extension, 41(6).

Gultekin, M., Cubukcu, Z., \& Dal, S. (2010). Ilkogretim ogretmenlerinin egitim ogretimle ilgili hizmet ici egitim gereksinimleri [In-service training needs of the primary school teachers regarding education-teaching]. Selcuk Universitesi Ahmet Kelesoglu Egitim Fakultesi Dergisi, 29, 131-152.

Gunes, F., \& Uygun, T. (2016). Ogretmen yetistirmede beceri uyusmazligi [Skill discrepancy in teacher education]. Ahi Evran Universitesi Sosyal Bilimler Enstitusu Dergisi, 2(3), 1-14.

Hanbury, C. (2008). The life skills handbook. December 20, 2015, from http://clarehanbury.typepad.com/life-skills-handbooks/6-FREE-LifeSkillsActivity Sessions.pdf. 
Hendricks, P. (1998). Targeting life skills model. Iowa State University Extension. Retrieved December 20, 2015, from http://www.extension.iastate.edu/4H.

Kaufman, K. J. (2013). 21 Ways to 21st century skills: Why students need them and ideas for practical implementation. Kappa Delta Pi Record, 49(2), 78-83. doi: 10.1080/00228958.2013.786594

Kennedy, F., Pearson, D., Brett-Taylor, L., \& Talreja, V. (2014). The life skills assessment scale: Measuring life skills of disadvantaged children in the developing world. Social Behaviour and Personality, 42(2), 197-210.

Kivunja, C. (2014). Do you want your students to be job-ready with 21st century skills? Change pedagogies: A pedagogical paradigm shift from Vygotskyian social constructivism to critical thinking, problem solving and siemens' digital connectivism. International Journal of Higher Education, 3(3), 81-91. doi:10.5430/ijhe.v3n3p81

Kivunja, C. (2015). Teaching students to learn and to work well with 21st century skills: Unpacking the career and life skills domain of the new learning paradigm. International Journal of Higher Education, 4(1), 1-11. doi: 10.5430/ijhe.v4n1p1

Koyuncu, K., \& Kavcar, N. (2016). Ogretmenlerin 2007 fizik programina ve uygulamalarina yonelik goruslerine kisisel ozelliklerinin etkisi [Effects of the teachers' personal features on their remarks about the 2007 secondary school physics curriculum and its applications]. Amasya Universitesi Egitim Fakultesi Dergisi, 5(2), 373-418. doi:10.17539/aej.33651

Kurtdede-Fidan, N., \& Aydogdu, B. (2018). Life skills from the perspectives of classroom and science teachers. International Journal of Progressive Education, 14(1), 32-55.

Lane, K.L., Pierson, M.R., \& Givner, C.C. (2004). Secondary teachers' views on social competence: Skills essential for success. The Journal of Special Education, 38(3), 174-186.

Larson, L.C., \& Miller, T.N. (2011) 21st century skills: Prepare students for the future. Kappa Delta Pi Record, 47(3), 121-123. doi: 10.1080/00228958.2011.10516575

OECD (2013). Teachers for the 21st century: Using evaluation to improve teaching. OECD Publishing.

OECD (2016). Skills matter: Further results from the survey of adult skills. Paris: OECD Publishing.

Ozturk, E., \& Bektas, M. (2018). Ogrencilerin okul oncesi egitimden ilkokula gecislerinde yasam becerilerini kazanmalarina yonelik ogretmen goruslerinin incelenmesi [Examination of teachers' opinions about the acquisition of the life skills of the students transitioning from preschool to primary school]. Journal of Human Sciences, 15(2), 1097-1115. doi:10.14687/jhs.v15i2.5365 
Partnership for 21st Century Skills (P21) (2015). P21 framework definitions. Retrieved April 01, 2018, from http://www.p21.org/our-work/p21-framework

Raja, W.D., Mullaikodi, M., \& Asaph, A. (2015). Personal and institutional impact on life skills among teacher educators. Paripex-Indian Journal of Research, 4(7), 55-57.

Saavedra, A.R., \& Opfer, V.D. (2012). Learning 21st-century skills requires 21stcentury teaching. Phi Delta Kappan, 94(2), 8-13.

Suminar, T., Prihatin, T., \& Syarif, M.I. (2016). Model of learning development on program life skills education for rural communities. International Journal of Information and Education Technology, 6(6), 496-499. doi: 10.7763/IJIET.2016.V6.739

Svanemyr, J., Baig, Q., \& Chandra-Mouli, V. (2015) Scaling up of life skills based education in Pakistan: A case study. Sex Education, 15(3), 249-262. doi: 10.1080/14681811.2014.1000454

The Turkish Ministry of National Education (TMNE) (2005). Ilkogretim fen ve teknoloji dersi 6, 7 ve 8. siniflar ogretim programi [Primary schools science and technology course curriculum for grades 6, 7, and 8]. Ankara: T.C. Milli Egitim Bakanligi.

The Turkish Ministry of National Education (TMNE) (2013). Ilkogretim kurumlari (ilkokullar ve ortaokullar) fen bilimleri dersi ogretim programi [Primary institutions (primary and middle schools) science course program]. Ankara: T.C. Milli Egitim Bakanligi.

The Turkish Ministry of National Education (TMNE) (2018). Fen bilimleri dersi ogretim programi [Science course curriculum]. Ankara: T.C. Milli Egitim Bakanligi.

Trilling, B., \& Fadel, C. (2009). 21st century skills: Learning for life in our times. San Francisco, CA: John Wiley \& Sons.

Turkish Education Association (TEA) (2009). Ogretmen yeterlilikleri ozet rapor [Teacher qualifications summary report]. Ankara: Turk Egitim Dernegi, Adim Okan Matbaacilik Basim Yayin.

Turkish Qualification Framework (TQF) (2015). Turkiye yeterlilikler cercevesi [Turkish qualification framework]. Ankara: Mesleki Yeterlilik Kurumu.

Ucar, R., \& Ipek, C. (2006). Ilkogretim okullarinda gorev yapan yonetici ve ogretmenlerin MEB hizmet ici egitim uygulamalarina iliskin gorusleri [The views of primary schools' administrators and teachers about in-service training programs in the Turkish educational system]. Yuzuncu Yil Universitesi Egitim Fakultesi Dergisi, 1(3), 34-53.

UNESCO. (2004). Report of the inter-agency working group on life skills in EFA. Paris: Unesco. 
United Nations. (2003). Life skills training guide for young people: HIV/AIDS and substance use prevention. New York: Economic and Social Commission for Asia and the Pacific.

Wallace, C. S., \& Priestley, M. (2011). Teacher beliefs and the mediation of curriculum innovation in Scotland: A socio-cultural perspective on professional development and change. Journal of Curriculum Studies, 43(3), 357-381. doi:10.1080/00220272.2011.563447

World Health Organization (WHO) (1997). Life skills education for children and adolescents in schools. Geneva: Programme on Mental Health World Health Organization.

Yildirim, A., \& Simsek, H. (2011). Sosyal bilimlerde nitel arastirma yontemleri [Qualitative research methods in the social sciences]. Ankara: Seckin Yayincilik.

\section{Fen Bilimleri Dersi Öğretim Programındaki Yaşam Becerileri ile İlgili Öğretmen Görüşleri}

Atıf:

Erduran-Avci, D., \& Kamer, D. (2018). Views of teachers regarding the life skills provided in science curriculum. Eurasian Journal of Educational Research, 77, 118, DOI: 10.14689 /ejer.2018.77.1

\section{Özet}

Problem Durumu: Yaşam becerileri bireylerin hayat boyunca karşılaştıkları sorunlarla başa çıkmalarını ve yaşamlarını etkili şekilde yönetmelerini sağlayan becerilerdir. Bu noktada yaşamın niteliğini ve değerini artırmak için yaşam becerilerine sahip olmanın gerekliliği kaçınılmazdır. Yaşam koşullarıyla baş etme gereksinimi küçük yaşlardan itibaren bireylerin yaşam becerileri eğitimleri almalarını zorunlu kılmaktadır. Bu kapsamda birçok ülke yaşam becerilerine okul programlarında yer vermekte, ihtiyaçlar doğrultusunda çeşitli yaşam becerisi kazandırmaya yönelik programlar geliştirmekte ve uygulamaktadır. Geçmişten günümüze Türkiye' de fen dersi programlarında yaşam becerileri kavramı ilk kez 2013-2014 öğretim yılında uygulamaya konulan Fen Bilimleri Dersi Öğretim Programı'nda (FBDÖP) bir öğrenme alt alanı olarak karşımıza çıkmaktadır. FBDÖP'teki yaşam becerileri alt öğrenme alanı; bilimsel bilgiye ulaşılması ve bilimsel bilginin kullanılmasına ilişkin analitik düşünme, karar verme, yaratıcılık, girişimcilik, iletişim ve takım çalışması gibi temel yaşam becerilerini kapsamaktadır. Öğrencilerin yaşam becerileri kazanmasında ve bu becerileri geliştirmesinde öğretmenlerinin önemli rollerden birine sahip olduğu düşünüldüğünde, öğretmenlerin yaşam becerilerine ilişkin algılarının ve bu becerilerin FBDÖP'de yer almasına ilişkin görüşlerinin neler olduğu soruları ortaya çıkmaktadır. 
Araştırmanın Amacı: Bu araştırmanın amacı, fen bilimleri öğretmenlerinin yaşam becerileri algılarını ve FBDÖP'te bir öğrenme alanı olarak yaşam becerilerinin yer almasını nasıl karşıladıklarını ortaya çıkarmaktır.

Araştırmanın Yöntemi: Bu araştırma, nitel araştırma yöntemlerinden biri olan durum çalışması olarak tasarlanmıştır. Araştırmanın çalışma grubunu 2013-2014 eğitim öğretim yılında Burdur ili merkezine bağlı ortaokullarda görev yapan ve araştırmaya gönüllü olarak katılmayı kabul eden fen bilimleri öğretmenleri oluşturmaktadır. Bu kapsamda 13 bayan, 13 erkek olmak üzere toplam 26 fen bilimleri öğretmeni araştırmaya katılmıştır. Veri toplama aracı olarak görüşme formu kullanılmıştır. Görüşme formunda; öğretmenlerin demografik özellikleri, yaşam becerilerinin onlar için ne ifade ettiği, bu becerilerin FBDÖP'te yer almasını nasıl karşıladıkları, alt yaşam becerisi alanlarını (analitik düşünme, karar verme, yaratıcı düşünme, girişimcilik, iletişim, ve takım çalışması) fen dersinde kazandırılmaya uygunluğu açısından nasıl değerlendirdikleri, kendi derslerinin bu becerilerin kazandırılmasında etkililiği, bu becerileri kazandırmak için nasıl uygulamalar yaptıkları, onları sınırlandıran ya da engelleyen durumlara ilişkin sorular yer almaktadır. Yarı yapılandırılmış olarak gerçekleşen görüşmeler ses kayıt cihazı ile kayıt edilmiştir. Veriler, betimsel ve içerik analizi yöntemleri kullanılarak analiz edilmiştir. Yazılı doküman haline getirilen veriler, anlamlı iki bölüme ayrılmıştır. Bu bölümler sırasıyla şunlardır; 'Öğretmenlerin yaşam becerileri algısı' ve 'FBDÖP'teki yaşam becerileri hakkında öğretmen görüşleri’. Bu bölümlerden ilki içerik analizi, ikincisi ise betimsel analiz ile gerçekleştirilmiştir.

Araştırmanın Bulguları: Öğretmenlerin yaşam becerileri hakkındaki görüşleri iki ana tema etrafında toplanmaktadır. Bu temalar fen okuryazarlığı ve 4-H yaşam becerileri olarak adlandırılmıştır. Araştırmanın bulguları öğretmenlerin çoğunun yaşam becerilerini fen okuryazarlığı olarak algıladığını, çok azının ise 4-H yaşam becerileri modelindeki bazı beceriler ile ilişkilendirdiğine işaret etmektedir. Bunun yanı sıra öğretmenlerin yarısı yaşam becerilerini hem fen okuryazarlığı hem de 4-H yaşam becerileri modelindeki düşünme, yönetme, bağlantı kurma, katkıda bulunma, yaşama ve olma becerileri olarak görmektedirler. Öğretmenlerin ifadeleri incelendiğinde fen okuryazarlığının 'anahtar fen kavramları', 'bilimsel süreç becerileri', 'fen-teknoloji-toplum-çevre' ve 'bilimsel ve teknik psikomotor beceriler' alt boyutları ile ilişkili olduğu görülmüştür. Hayatın getirdiği her türlü sorunla başa çıkmaya yönelik ve kişilerin kendi bireysel dünyasında veya sosyal yaşamında başarılı olmalarını sağlamaya yönelik öğretmen görüşleri $4-\mathrm{H}$ yaşam becerileri modelindeki bazı becerilerle ilişkilendirilmiştir. Sorumlu olma, ileriyi görebilme, hayata uyum sağlama, dürüst olma, özgüven, zaman yönetimi, mücadele etme, başarılı olma, iletişim kurabilme gibi beceriler bu temada ele alınmıştır. Öğretmenlerin ifadeleri 4-H kapsamındaki sekiz yaşam becerisi temasından altısıyla uyumlu bulunmuştur.

Öğretmenlerin neredeyse tamamının yaşam becerilerinin FBDÖP’te yer aldığını fark etmediği görülmüştür. Ancak çoğunluğu bu becerileri fen derslerinde kazandırılmaya uygun beceriler olarak görmektedirler. Bu becerileri en çok proje çalışmaları ve deneylerle kazandırabileceklerini düşünmektedirler. 
Araştırmanın Sonuçları ve Öneriler: Öğretmenlerin çoğu yaşam becerilerini fen okuryazarlığı olarak algılamaktayken, bazıları 4 -H yaşam becerileri modelindeki bazı beceriler ile ilişkilendirmişlerdir. Aslında neyin yaşam becerisi olup neyin olmadığ konusunda literatürde bir fikir birliği sağlanmış değildir. Bununla birlikte bu araştırmaya katılan çoğu öğretmenin yaşam becerilerini fen okuryazarlığı olarak algılamasının nedeni FBDÖP'ün vizyonuyla ilişkilendirilebilir. Öğretmenlerin yarıdan daha azı bu becerilere yaşamın herhangi bir alanında karşılaşılabilecek kişisel sorunları yönetmeyi ve bu sorunları çözmeyi içeren daha geniş anlamlı bir pencereden bakarken, çoğu yaşam becerilerini özellikle kendi alanlarıla (fen) sınırlı olarak algılamaktadırlar. Öğretim programı kapsamında bakıldığında öğretmenlerin yaşam becerileri farkındalıklarının düşük olduğu görülmüştür. Öğretmenler FBDÖP'te alt yaşam becerileri olarak yer verilen analitik düşünme, karar verme, yaratıcı düşünme, girişimcilik, iletişim ve takım çalışması becerilerini geliştirmeye yönelik zaman zaman etkinlikler gerçekleştirdiklerini ve bu becerilerin bireylerde olması gereken özellikler olduğuna inanmalarına rağmen, bu becerilerin FBDÖP'te yer aldığını bilmemektedirler. Bununla birlikte öğretmenler fen derslerinin bu tür yaşam becerileri geliştirmeye oldukça uygun bir ders olduğunu düşünmekte ve bu becerileri önemsenmesi gerektiğine inanmaktadır.

Bireylere ihtiyaç duydukları becerilerin kazandırılmasında en önemli paydaşlar arasında eğitim kurumları ve eğitimciler gelmektedir. Ülkelerin koşul ve ihtiyaçları baz alınarak öğretim programlarının içeriklerinin yaşam becerileri açısından değerlendirilmesi ve öğretmenlerin bu konudaki ihtiyaçları, yeterlilikleri, onları teşvik eden ve sınırlandıran durumlar hakkındaki görüşleri gibi birçok konuyu derinlemesine inceleyecek araştırmalara ve hizmet içi eğitimlere ihtiyaç olduğu düşünülmektedir.

Anahtar Kelimeler: 4-H yaşam becerileri, fen okuryazarlığı, öğretmen görüşleri, fen bilimleri dersi. 